\title{
SHORT-TERM ASSESSMENT OF Bt MAIZE ON NON-TARGET ARTHROPODS IN BRAZIL
}

\author{
Odair Aparecido Fernandes ${ }^{1 *}$; Marcos Faria ${ }^{2}$; Samuel Martinelli³; Francisco Schmidt²; \\ Vinícius Ferreira Carvalho"; Gloverson Moro ${ }^{5}$ \\ ${ }^{1}$ UNESP/FCAV, Depto. de Fitossanidade, Via de acesso Prof. Paulo Donato Castellane, s/n - 14884-900 \\ Jaboticabal, SP - Brasil. \\ ${ }^{2}$ Embrapa Recursos Genéticos e Biotecnologia, Parque Estação Biológica, Av. W5 Norte - 70770-900 - Brasília, \\ DF - Brasil. \\ ${ }^{3}$ USP/ESALQ - Programa de Pós-Graduação em Entomologia, C.P. 9 - 13418-900 - Piracicaba, SP - Brasil. \\ ${ }^{4}$ Conselho de Informações sobre Biotecnologia - CIB, R. André Ampére, 34 - Unidade 12, Brooklin - 04562-080 - \\ São Paulo, SP - Brasil. \\ ${ }^{5}$ Syngenta Seeds Ltda., Rod. BR 452 - km 142, C.P. 585 - 38400-974 - Uberlândia, MG - Brasil. \\ *Corresponding author<oafernandes@fcav.unesp.br>
}

ABSTRACT: Although not yet available for cultivation in Brazil, the effect of Bt maize hybrids on natural enemies and soil dwelling arthropods should be assessed prior to its release to growers. Trials were carried out during one growing season in two different locations with the genetically modified maize hybrids 7590-Bt11 and Avant-ICP4, comparing with their respective non-Bt isogenic hybrids. Arthropods were evaluated through direct observation on plants and pitfall traps. In general, no differences were observed between populations of earwig (Dermaptera: Forficulidae), lady beetles (Coleptera: Coccinellidae), minute pirate bug (Coleoptera: Anthocoridae), ground beetles (Carabidae), tiger beetles (Cicindelidae), and spiders (Araneae). There was no difference in egg parasitism of Helicoverpa zea (Boddie) by Trichogramma sp. (Hymenoptera: Trichogrammatidae). Thus, Bt maize hybrids expressing insecticide proteins Cry1A(b) and VIP 3A do not cause reduction of the main maize dweeling predators and parasitoids.

Key words: Spodoptera frugiperda, Helicoverpa zea, genetically modified crop, maize pests, soil dwelling arthropods

\section{AVALIAÇÃO DO EFEITO DE MILHO Bt SOBRE ARTRÓPODOS NÃO ALVO NO BRASIL}

RESUMO: Embora não haja cultivos comerciais de milho geneticamente modificado no Brasil, o efeito de híbridos de milho Bt sobre inimigos naturais e artrópodos de solo deve ser avaliado antes da liberação aos produtores. Assim, ensaios foram conduzidos durante uma safra em duas localidades. Os híbridos de milho modificado geneticamente 7590-Bt11 e Avant-ICP4 foram comparados com seus respectivos isogênicos não transgênicos. Os artrópodes foram avaliados através de observação direta nas plantas e armadilhas de alçapão. De modo geral, não se observaram diferenças entre as populações de tesourinha (Dermaptera: Forficulidae), joaninhas (Coleptera: Coccinellidae), percevejo-pirata (Coleoptera: Anthocoridae), carabídeos (Carabidae), cicindelídeos (Cicindelidae) e aranhas (Araneae). Também não houve diferença no parasitismo de ovos de Helicoverpa zea (Boddie) por Trichogramma sp. (Hymenoptera: Trichogrammatidae). Assim, milho geneticamente modificado expressando as proteínas inseticidas Cry1A(b) e VIP 3A não causa redução nas populações dos principais predadores e parasitóides.

Palavras-chave: Spodoptera frugiperda, Helicoverpa zea, cultura geneticamente modificada, pragas do milho, artrópodes de solo

\section{INTRODUCTION}

Genetically modified (GM) plants resistant to insects through the expression of Bacillus thuringiensis Berliner bacterial toxins $(\mathrm{Bt})$ are considered a new pest management alternative for farmers. This technology has made possible the efficient and specific control of certain lepidopterous pests (Buntin et al., 2001; Stewart et al., 2001; Wu et al., 2003; Kumar \& Kumar, 2004). Although already commercially available in several countries (Nap et al., 2003), the use of both Bt cotton and maize in Brazil is currently restricted to experi- 
mental areas (Fontes, 2003). Thus, studies that assess not only the agronomic efficacy, but also the effects of GM plants on natural enemies and other non-target arthropods associated with GM crops are needed (Conner et al., 2003).

Egg parasitoids and predators of maize pests were not negatively affected by Bt maize expressing Cry1A(b) protein (Orr \& Landis, 1997; Pilcher et al., 1997; Zwahlen et al., 2000; Al-Deeb et al., 2001). When fed with prey tolerant to the Cry1A(b) toxin, the mortality and development of the predator Chrysoperla carnea (Stephens) were not affected (Hilbeck et al., 1998a). On the other hand, Hilbeck et al. (1998b) observed that a high dose of the Cry1A(b) protein incorporated into an artificial solid diet provided to $C$. carnea larvae caused significantly greater mortality than the control. Romeis et al. (2004) showed that the Cry1A(b) toxin had no direct effect on C. carnea. These authors argued that earlier reported negative effects of $\mathrm{Bt}$ maize on these predators were due to prey quality mediated effects rather than to the direct effects of the toxin.

To date, studies to determine the effect of GM plants on non-target organisms in tropical areas, thus with greater biodiversity, have been rare (O'Callaghan et al., 2005, for review). Thus, the objective of this study was to evaluate the effects of two genetically modified hybrids expressing $B$. thuringiensis insecticide proteins and their isogenic non-transgenic hybrids on herbivore natural enemies that occur in the Brazilian maize agroecosystem.

\section{MATERIAL AND METHODS}

Experiment Location - The experiments were con-

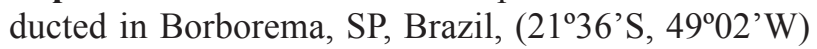
and Uberlândia, MG, Brasil, (18 $\left.56^{\circ} \mathrm{S}, 48^{\circ} 10^{\prime} \mathrm{W}\right)$ and were duly authorized by the Comissão Técnica Nacional de Biossegurança (CTNBio, National Technical Biosafety Commission), under proceedings no. 01200.002643/99-17 and 01200.002642/99-54, respectively. Both sites are located in the southeastern region of Brazil ca. $350 \mathrm{~km}$ apart. Borborema is located closer to a maize growing area but has a greater diversity of crops. Citrus, pasture, coffee, sugarcane and soybean are also grown in the municipality. On the other hand, Uberlândia is located in one of the most important maize growing regions of Brazil. Thus, the diversity of crops in the region is much lower.

Genetically Modified Organisms - Treatments included the maize hybrids GM 7590-Bt11 and AvantICP4 and their respective non-Bt isogenic hybrids. The hybrids from events Bt11 and ICP4 have genes isolated from $B$. thuringiensis var. kurstaki expressing the insecticide proteins Cry1A(b) and VIP 3A (Estruch et al., 1996), respectively with toxic properties for certain species of Lepidoptera. The genetically modified versions of the inbreds used to produce the GM hybrids are the result of four generations of backcrosses followed by two generations of self-pollinations (BC4S2). These BC4S2 versions were selected for homozigousity of the transgenic trait, as well as, phenotypic similarity to their original progenitors.

Crop Management - Soil tillage and other crop management practices were performed following the technical recommendation for maize (Fancelli \& Dourado Neto, 2000), using non-treated seeds. Crops were sown on December 181999 (Borborema) and December 3 1999 (Uberlândia) using 0.75 to $0.80 \mathrm{~m}$ spacing between rows and six seeds per row meter. As a biosafety measure, the experimental plots containing GM plants were detasseled (biosafety mandatory procedure) to prevent pollen dispersion from the genetically modified plants in the study area. The plots with Bt maize plants had two rows of plants from the respective isogenic non-Bt cultivar to provide pollen and assure further production.

Experimental Design - The statistical design consisted of randomized complete blocks (RCB) with four treatments and three replications. Each experimental unit was $40 \mathrm{~m}$ long by 15 rows wide. Three rows of the non-GM maize were kept as lateral border around the experimental area. In Uberlândia, the isogenic non-Bt of the Bt11 maize had only two replications.

Evaluation of Non-target Arthropods - Evaluations were made weekly, beginning on the $4^{\text {th }}$ week after planting ( $4^{\text {th }}$ WAP) and ending on the $16^{\text {th }}$ WAP (Borborema) or $17^{\text {th }}$ WAP (Uberlândia). Predator occurrence was evaluated on ten consecutive plants per sampling site. Three randomly chosen sites were evaluated in each plot, totaling 30 plants per plot. In the plots containing Bt maize, the rows of plants providing pollen were not considered for sampling. The target arthropods in this evaluation were the main predators and parasitoids present in the maize system: earwig adults and nymphs, predator hemipterans, lady beetles, spiders, and Trichogramma spp. All predators but earwig nymphs were counted on each plant. For earwig nymphs, the presence/absence on the plants was considered, regardless the number of insects. Parasitism by Trichogramma was assessed through observation of parasitized Helicoperva zea (Boddie) eggs as suggested by Paron et al. (1998).

A survey of natural enemies that occur in the soil was conducted using pitfall traps, made of $500 \mathrm{~mL}$ 
plastic bottles buried in the soil surface layer. Five traps were randomly placed in each plot. Each trap received $200 \mathrm{~mL}$ of $70 \%$ ethanol to preserve the trapped insects. The traps were installed on the $11^{\text {th }}$ and $15^{\text {th }}$ WAP at Borborema and on the $10^{\text {th }} \mathrm{WAP}$ at Uberlândia and kept in the field for seven days.

Statistical Analyses - The number of natural enemies per plant and the percentage of plants with earwig nymphs at each sampling site were used for the calculation of averages in each experimental plot. The averages of natural enemies were transformed to $\sqrt{x+0.5}$ and used in the analysis of variance. The percentage of parasitism values were computed as described above and transformed to arc sine $\sqrt{\% / 100}+0.5$. Data were submitted to analysis of variance in a randomized complete block design with repeated measures. The plots were treatments and the weeks after planting were the sub plots. In this way, it was possible to estimate the interaction between treatments and weeks after planting. Data were estimated for the missing plot at Uberlândia. The results of the number of insects collected in the pitfall traps were also transformed to $\sqrt{x+0.5}$ and an analysis of variance was conducted in a randomized complete block design. In the occasions when the F test for treatments was significant, the hybrids were compared using orthogonal contrast estimates. Thus, the conventional hybrid group was compared with its respective GM counterparts, Bt11 and ICP4. However, a comparison between the hybrids expressing different toxins was
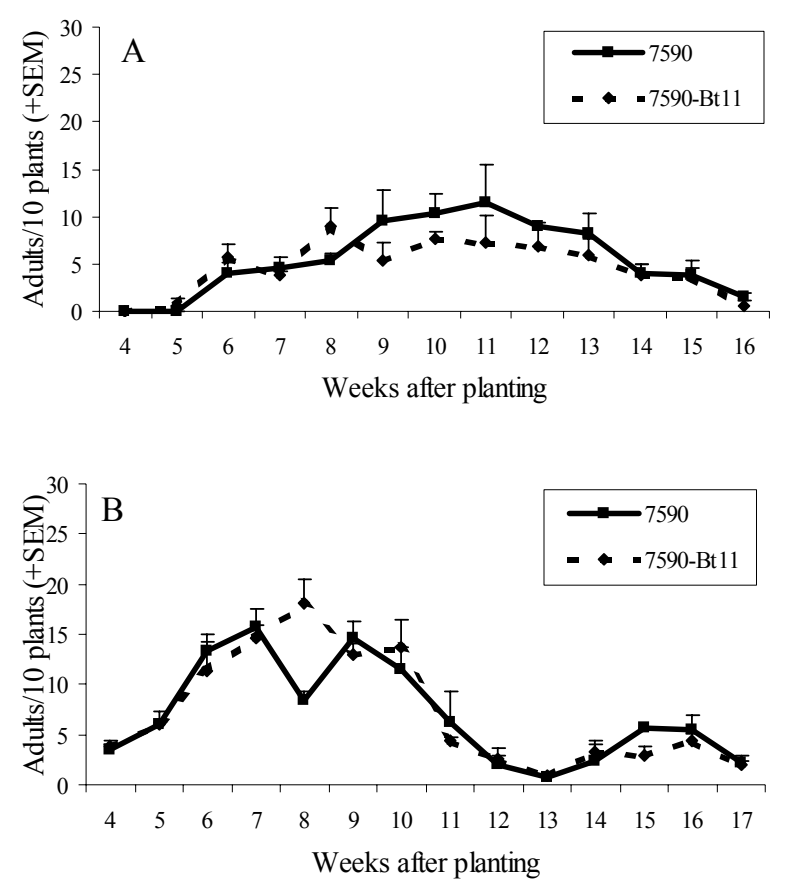

not made because they had different phenotypes. Moreover, the results between the two experimental locations were not compared. Bartlett's test was used to evaluate the homogeneity of the variance. Transformation was necessary to normalize the data and stabilize the variance. Statistical analyses were performed using PROC GLM (SAS Institute, 1999).

\section{RESULTS}

No differences were observed between the $\mathrm{Bt}$ hybrids and their respective isogenic non-Bt genotypes regarding the average number of earwig, Doru luteipes (Scudder), adults per ten plants throughout the crop cycle (Figure 1). The estimate of the orthogonal contrasts showed no difference between the maize hybrids and their respective non-Bt isogenic for the percentage of plants with presence of nymphs (Table 1), although minor differences were observed between maize genetic backgrounds (Group 7590 versus Group Avant) at the Uberlândia site.

There was no difference in the number of predator hemipterans occurring on 7590-Bt11 and 7590 hybrids at Borborema $(P=0.23)$ and Uberlândia $(P=0.99)$. However, there were more predator hemipterans on the Avant-ICP4 hybrid than on its non-genetically modified version at Borborema $(P=0.0394)$. At Uberlândia, no difference between these two hybrids was observed $(P=0.28)$ (Table 2$)$. The hemipterans found belonged to several families, mainly
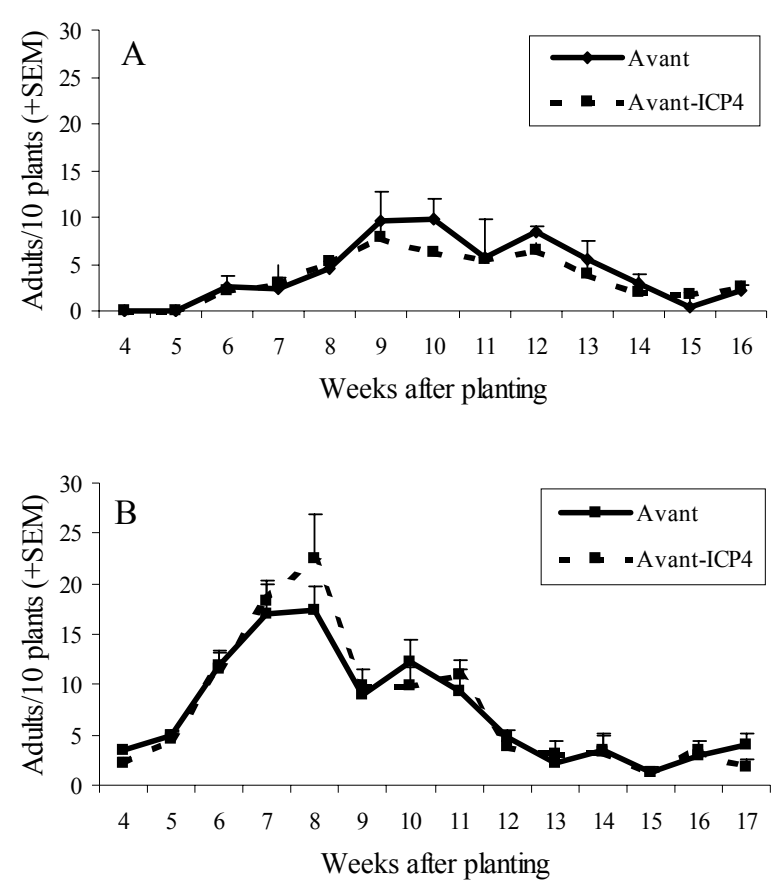

Figure 1- Mean density of Doru luteipes (Dermaptera: Forficulidae) adults per ten plants of genetically modified maize and isogenic non-Bt maize throughout the growing season at Borborema, SP (A) and Uberlândia, MG (B). 
Table 1 - Percent ${ }^{1}( \pm$ SEM) of maize plants with presence of Doru luteipes nymphs and the estimated orthogonal contrasts.

\begin{tabular}{lcc}
\hline Maize Hybrids & Borborema, SP & Uberlândia, MG \\
\hline 7590 & $63.52 \pm 4.08$ & $56.33 \pm 7.03$ \\
$7590-$ Bt11 & $66.48 \pm 4.24$ & $60.67 \pm 5.17$ \\
Avant & $67.78 \pm 3.73$ & $53.56 \pm 5.75$ \\
Avant-ICP4 & $75.74 \pm 3.36$ & $52.33 \pm 5.00$ \\
\hline Contrasts & & 0.0084 \\
\hline Group 7590 vs Group Avant & 0.0246 & 0.5864 \\
$7590-$ Bt11 vs 7590 & 0.4425 & 0.4918 \\
\hline
\end{tabular}

${ }^{1}$ Original values are shown but they were transformed to arcsine $\sqrt{\% / 100}+0.5$ for statistical analysis.

Table 2 - Average number ${ }^{1}( \pm$ SEM) of adult predator hemipterans, lady beetles, and spiders per ten plants and the estimated orthogonal contrasts.

\begin{tabular}{|c|c|c|c|}
\hline Arthropod Group & Maize Hybrids & Borborema, SP & Uberlândia, MG \\
\hline \multirow[t]{8}{*}{ Predator hemipterans } & 7590 & $0.470 \pm 0.103$ & $0.048 \pm 0.029$ \\
\hline & $7590-$ Bt11 & $0.385 \pm 0.094$ & $0.071 \pm 0.021$ \\
\hline & Avant & $0.709 \pm 0.179$ & $0.151 \pm 0.034$ \\
\hline & Avant-ICP4 & $0.880 \pm 0.176$ & $0.222 \pm 0.043$ \\
\hline & Contrasts & & \\
\hline & Group 7590 vs Group Avant & 0.0006 & 0.0243 \\
\hline & $7590-\mathrm{Bt} 11$ vs 7590 & 0.2332 & 0.9900 \\
\hline & Avant-ICP4 vs Avant & 0.0394 & 0.2800 \\
\hline \multirow[t]{8}{*}{ Lady beetles } & 7590 & $0.333 \pm 0.074$ & $0.036 \pm 0.020$ \\
\hline & $7590-\mathrm{Bt} 11$ & $0.479 \pm 0.101$ & $0.048 \pm 0.021$ \\
\hline & Avant & $0.718 \pm 0.217$ & $0.032 \pm 0.016$ \\
\hline & Avant-ICP4 & $0.692 \pm 0.147$ & $0.056 \pm 0.023$ \\
\hline & Contrasts & & \\
\hline & Group 7590 vs Group Avant & 0.0358 & 0.9075 \\
\hline & $7590-$ Bt11 vs 7590 & 0.3313 & 0.9634 \\
\hline & Avant-ICP4 vs Avant & 0.9238 & 0.4766 \\
\hline \multirow[t]{8}{*}{ Spiders } & 7590 & $0.376 \pm 0.097$ & $0.012 \pm 0.012$ \\
\hline & $7590-\mathrm{Bt} 11$ & $0.393 \pm 0.089$ & $0.032 \pm 0.015$ \\
\hline & Avant & $0.376 \pm 0.068$ & $0.079 \pm 0.037$ \\
\hline & Avant-ICP4 & $0.718 \pm 0.156$ & $0.048 \pm 0.019$ \\
\hline & Contrasts & & \\
\hline & Group 7590 vs Group Avant & 0.0021 & 0.3496 \\
\hline & $7590-\mathrm{Bt} 11$ vs 7590 & 0.5644 & 0.7881 \\
\hline & Avant-ICP4 vs Avant & 0.0006 & 0.6115 \\
\hline
\end{tabular}

${ }^{1}$ Original values are shown but they were transformed to $\sqrt{x+0.5}$ for the statistical analysis.

Reduviidae, Anthocoridae, Lygaeidae, and Pentatomidae. The pirate bug Orius insidiosus (Say) was the predominant species in Borborema, while in Uberlândia predator hemipterans occurred at low densities and no dominant species was detected.

Regarding lady beetles and spiders, the average density of predators was less than 0.08 per plant (Table 2). The population of Coccinellidae and Aranae were at least 4- and 9-fold higher in Borborema than in Uberlândia, respectively. In Borborema, there were more spiders $(P=0.0006)$ in the Avant-ICP4 hybrid than in the isogenic non-Bt hybrid (Table 2).

There was no difference between the maize hybrids $(P=0.42$ for GM $7590 \mathrm{Bt} 11$ vs. its isogenic non-Bt and $P=0.60$ for Avant-ICP4 vs. its non-Bt) in percentage of parasitism of $H$. zea eggs by 
Trichogramma sp. at the Borborema location (Table 3). The average rate of parasitism was always greater than $29 \%$. At Borborema, 1.31 viable egg of $H$. zea per plant were found on Avant-ICP4, while 0.53 egg per plant was observed on its non-Bt isogenic. An average of 0.24 and 0.50 egg per plant were observed on the 7590-Bt11 hybrid plants and its non-Bt isogenic,

Table 3 - Average percentage of parasitism ( \pm SEM) of Helicoverpa zea eggs in Borborema, SP.

\begin{tabular}{lc}
\hline Maize Hybrids & $\begin{array}{c}\text { Parasitism of H. zea } \\
\text { eggs }(\%)^{1}\end{array}$ \\
\hline 7590 & $31.14 \pm 10.91$ \\
$7590-B t 11$ & $29.35 \pm 6.04$ \\
Avant & $36.58 \pm 11.08$ \\
Avant-ICP4 & $32.40 \pm 9.24$ \\
\hline Contrasts & $P$ \\
\hline Group 7590 vs Group Avant & 0.9393 \\
$7590-B t 11$ vs 7590 & 0.4243 \\
Avant-ICP4 vs Avant & 0.5962 \\
\hline${ }^{1}$ Original values are shown but they were transformed to arcsine \\
$\sqrt{\%} / 100+0.5$ for the statistical analysis.
\end{tabular}

respectively. Parasitism of $H$. zea eggs was not evaluated at Uberlândia.

At Borborema, in the first evaluation of predators collected in the pitfall traps, there was a difference $(P=0.0018)$ between the treatments Avant and Avant-IPC4 for the number of rover beetles (Table 4). In the second evaluation, there was no difference between the treatments for any of the evaluated predator arthropods (Table 4). At the Uberlândia location there was no difference in predator arthropods between the Bt hybrids and their isogenic non-Bt hybrids (Table 4). Overall, both Borborema and Uberlândia presented no differences in population densities between the treatments for tiger beetles (Cicindelidae), ground beetles (Carabidae), earwigs (Forficulidae), rover beetles (Staphilinidae) and spiders (Aranae) collected in pitfall traps. Tiger beetles were not observed at the Uberlândia plots.

\section{DISCUSSION}

In general, the Bt maize hybrids did not affect the $D$. luteipes population dynamics and other biologi-

Table 4- Average number of predators $( \pm$ SEM) in pitfall traps and the estimated orthogonal contrasts.

\begin{tabular}{|c|c|c|c|c|c|c|c|}
\hline \multirow{2}{*}{ Location } & \multirow{2}{*}{ Sampling } & \multirow{2}{*}{ Maize Hybrids } & \multicolumn{5}{|c|}{ Arthropod Group ${ }^{1}$} \\
\hline & & & Cicindelidae & Carabidae & Staphilinidae & Forficulidae & Araneae \\
\hline \multirow[t]{12}{*}{$\begin{array}{l}\text { Borborema, } \\
\text { SP }\end{array}$} & 1 & 7590 & $1.75 \pm 0.27$ & $0.93 \pm 0.41$ & $4.20 \pm 1.17$ & $0.07 \pm 0.07$ & $1.17 \pm 0.38$ \\
\hline & & $7590-\mathrm{Bt} 11$ & $4.07 \pm 0.93$ & $1.07 \pm 0.24$ & $2.47 \pm 1.01$ & $0.13 \pm 0.13$ & $1.00 \pm 0.12$ \\
\hline & & Avant & $2.18 \pm 0.72$ & $2.70 \pm 0.70$ & $17.87 \pm 1.30$ & $0.00 \pm 0.00$ & $0.17 \pm 0.17$ \\
\hline & & Avant-ICP4 & $1.73 \pm 0.27$ & $2.15 \pm 0.18$ & $5.45 \pm 1.85$ & $0.15 \pm 0.08$ & $0.85 \pm 0.08$ \\
\hline & & Contrasts & & & $P$ & & \\
\hline & & Group 7590 vs Group Avant & - & 0.0017 & 0.0013 & - & - \\
\hline & & $7590-\mathrm{Bt} 11$ vs 7590 & - & 0.5909 & 0.2476 & - & - \\
\hline & & Avant-ICP4 vs Avant & - & 0.3163 & 0.0018 & - & - \\
\hline & 2 & 7590 & $0.45 \pm 0.23$ & $0.08 \pm 0.08$ & $3.38 \pm 0.71$ & $0.27 \pm 0.18$ & $0.27 \pm 0.13$ \\
\hline & & $7590-\mathrm{Bt} 11$ & $0.93 \pm 0.35$ & $0.47 \pm 0.18$ & $2.53 \pm 0.69$ & $0.20 \pm 0.12$ & $0.47 \pm 0.18$ \\
\hline & & Avant & $0.15 \pm 0.08$ & $0.17 \pm 0.17$ & $7.80 \pm 3.11$ & $0.07 \pm 0.07$ & $0.40 \pm 0.23$ \\
\hline & & Avant-ICP4 & $0.00 \pm 0.00$ & $0.22 \pm 0.02$ & $4.82 \pm 1.79$ & $0.22 \pm 0.02$ & $0.42 \pm 0.19$ \\
\hline \multirow[t]{8}{*}{$\begin{array}{l}\text { Uberlândia, } \\
\text { MG }\end{array}$} & 1 & 7590 & & $0.70 \pm 0.30$ & $0.10 \pm 0.10$ & $0.30 \pm 0.10$ & $0.70 \pm 0.10$ \\
\hline & & $7590-\mathrm{Bt} 11$ & & $0.33 \pm 0.18$ & $0.73 \pm 0.55$ & $0.40 \pm 0.31$ & $0.27 \pm 0.07$ \\
\hline & & Avant & & $1.27 \pm 0.27$ & $0.73 \pm 0.47$ & $0.93 \pm 0.64$ & $0.53 \pm 0.29$ \\
\hline & & Avant-ICP4 & & $2.93 \pm 0.84$ & $1.20 \pm 0.40$ & $0.47 \pm 0.29$ & $0.47 \pm 0.18$ \\
\hline & & Contrasts & & & $P$ & & \\
\hline & & Group 7590 vs Group Avant & & - & 0.0207 & - & - \\
\hline & & $7590-B+11$ vs 7590 & & - & 0.5709 & - & - \\
\hline & & Avant-ICP4 vs Avant & & - & 0.0818 & - & - \\
\hline
\end{tabular}

${ }^{1}$ Original values are shown but they were transformed to $\sqrt{x+0.5}$ for the statistical analysis. 
cal control agents, despite the fact of a reduction in population densities of lepidopteran pests (Martinelli, 2001).

Earwigs, the primary natural enemies of lepidopteran larvae occurring on maize in Brazil (Cruz \& Oliveira, 1997), were the most frequent predators on plants during all phenological stages of the crop. The densities observed for this insect were greater than the other natural enemies that occur in maize. Eggs, small larvae $\left(1^{\text {st }}\right.$ and $2^{\text {nd }}$ instars $)$ of both fall armyworm, Spodoptera frugiperda (J.E. Smith), and corn earworm, $H$. zea, and aphid nymphs are important components of the D. luteipes diet (Reis et al., 1988). Even with a lower availability of Lepidoptera larvae, occurrence of $D$. luteipes was not impacted in GM plots.

There was no difference in the occurrence of lady beetles, both in Borborema and Uberlândia. The absence of adverse effects of the Bt maize hybrids on adult Coccinellidae was also observed in field and laboratory studies by Pilcher et al. (1997). In their study conducted for two consecutive years, no difference occurred on non-transgenic and Bt hybrids in the number of several Coccinellidae species. Likewise, there was no difference in the occurrence of predatory hemipterans, on $\mathrm{Bt}$ and non-Bt hybrids in Borborema and Uberlândia, although the Avant-ICP4 maize hybrid presented a higher density of such predators at the former location. Similarly, experiments conducted in the laboratory showed that keeping nymphs of $O$. insidiosus with maize Bt pollen did not affect insect survival (Pilcher et al., 1997). Al-Deeb et al. (2001) and Al-Deeb \& Wilde (2003) also did not find a significant difference in the number of adults and nymphs of $O$. insidiosus in fields of $\mathrm{Bt}$ maize and non-genetically modified maize. Hemipterans belonging to the genus Orius consume small lepidopteran larvae, thrips (Flint \& Dreistadt 1998), and pollen (Orr \& Landis 1997). During this research, thrips were detected throughout the developing cycle of the maize plants in all treatments. Supporting this interaction between thrips and Orius sp, no adverse effect was detected for the feeding of $O$. majusculus with thrips that had developed on maize plants expressing the Cry1 $\mathrm{A}(\mathrm{b})$ protein (Zawhlen et al., 2000).

Spiders and other generalist predator occurrence was not affected by Bt maize plants either. Parasitism of $H$. zea eggs by Trichogramma sp. was also not affected, suggesting that the foraging behavior of females was not hampered by Bt plants. The observed data support a field study conducted by Orr \& Landis (1997) in which the parasitism rate of egg masses of $O$. nubilalis in $\mathrm{Bt}$ maize growing areas was not reduced. Herbivore insects considered of secondary im- portance, such as aphids and thrips that occurred in the experimental areas (unpublished data), may contribute to the population stability of predators and parasitoids, when there are lower populations of the target lepidopteran pests that attack maize hybrids.

Raps et al. (2001) detected that the bird cherryoat aphid, Rophalosiphum padi (L.), an important prey for beneficial insects, contained very low concentrations, or, in many cases, no CrylA(b) toxin in their bodies or in their honeydew. Generally, in this study we found a great diversity despite the low density of arthropods per plant observed in all treatments. Other crops in the neighborhood may have contributed to the observed diversity of insect groups. In Borborema, the maize crop was surrounded by citrus, coffee, sugarcane, soybeans, and pasture, while in Uberlândia, where generally a lower abundance of natural enemies was observed, there were only plantings of maize and soybeans in the neighboring fields. Evaluation of larger areas than the ones used in this experiment may contribute to a better understanding of the real effect of transgenic plants on the food network. In the present study, parasitoids other than Trichogramma were not observed in the experimental areas.

Overall, the evidence collected throughout the production cycle of maize in Borborema and Uberlândia indicated that the use of Bt maize did not impact populations of non-target arthropods.

\section{ACKNOWLEDGEMENT}

To Dr. Robert Peterson, Montana State University, for critically reviewing the manuscript.

\section{REFERENCES}

AL-DEEB, M.A.; WILDE, G.E. Effect of corn expressing the Cry3Bb1 toxin for corn rootworm control on aboveground nontarget arthropods. Biological Control, v.32, p.1164-1170, 2003.

AL-DEEB, M.A.; WILDE, G.E.; HIGGINS, RA. No effect of Bacillus thuringiensis corn and Bacillus thuringiensis on the predator Orius insidiosus. Environmental Entomology, v.30, p.624-629, 2001.

BUNTIN, G.D.; LEE, R.D.; WILSON, D.M.; McPHERSON, R.M. Evaluation of yieldgard resistance for fall armyworm and corn earworm (Lepidoptera: Noctuidae) on corn. Florida Entomologist, v.84, p.38-42, 2001.

CONNER, A.J.; GLARE, T.R.; NAP, J.P. The release of genetically modified crops into the environment. Part II. Overview of ecological risk assessment. The Plant Journal, v.33, p.19-46, 2003.

CRUZ, I.; OLIVEIRA, A.C. Flutuação populacional do predador Doru luteipes Scudder em plantas de milho. Pesquisa Agropecuária Brasileira, v.32, p.363-368, 1997.

ESTRUCH, J.J.; WARREN, G.W.; MULlinS, M.A.; NYE, G.J.; CRAIG, J.A.; KOZIEL, M.G. VIP3A, a novel Bacillus thuringiensis vegetative insecticidal protein with a wide spectrum of activities against lepidopteran insects. Proceedings of the National Academy of Sciences of the USA, v.93, p.5389-5394, 1996.

FANCELLI, A.L.; DOURADO NETO, D. Produção de milho. Guaiba: Agropecuária, 2000. 360p. 
FLINT, M.L.; DREISDADT, S.H. Natural enemies handbook: The illustrated guide to biological control. Berkeley: University of California Press, 1998.154p.

FONTES, E.M.G. Legal and regulatory concerns about transgenic plants in Brazil. Journal of Invertebrate Pathology, v.83, p.100-103. 2003.

HILBECK, A.; BAUMGARTNER, M.; FRIED, P.M.; BIGLER, F. Effects of Bacillus thuringiensis corn-fed prey on mortality and development time of immature Chrysoperla carnea (Neuroptera: Chrysopidae). Environmental Entomology, v.27, p.480-487, 1998a.

HILBECK, A.; MOAR, W.J.; PUSZTAI-CAREY, M.; FILIPPINI, A.; BIGLER, F. Toxicity of Bacillus thuringiensis Cry1 Ab toxin to the predator Chrysoperla carnea (Neuroptera: Chrysopidae). Environmental Entomology, v.27, p.1255-1263, 1998b.

KUMAR, H.; KUMAR, V. Tomato expressing Cry1A(b) insecticidal protein from Bacillus thuringiensis protected against tomato fruit borer, Helicoverpa armigera (Hübner) (Lepidoptera: Noctuidae) damage in the laboratory, greenhouse and field. Crop Protection, v.23, p.135-139, 2004.

MARTINELLI, S. Efeito de híbridos de milho Bt expressando toxinas de Bacillus thuringiensis Berliner sobre insetos herbívoros e agentes de controle. Ribeirão Preto: USP/FFCLRP, 2001. 139p. (Dissertação - Mestrado).

NAP, J.P.; METS, P.L.J.; ESCALER, M.; CONNER, A.J. The release of genetically modified crops into the environment. The Plant Journal, v.33, p.1-18, 2003.

O'CALLAGHAN, M., GLARE, T.R.; BURGESS, E.P.J.; MALONE, L.A. Effects of plants genetically modified for insect resistance on nontarget organisms. Annual Review of Entomology, v.50, p.271292, 2005.

ORR, D.B.; LANDIS, D.A. Oviposition of European corn borer (Lepidoptera: Noctuidae) and impact of natural enemy population in transgenic versus isogenic corn. Journal of Economic Entomology, v.90, p.805-809, 1997.

PARON, M.J.F.O.; CRUZ, I.; CIOCIOLA, A.I. Efeito de genótipos de milho no parasitismo por Trichogramma spp. em ovos de Helicoverpa zea (Boddie). Anais da Sociedade Entomológica do Brasil, v.27, p.435-441, 1998.
PILCHER, C.D.; OBRYCKI, J.J.; RICE, M.E.; LEWIS, L.C. Preimaginal development, survival and field abundance of insect predators of transgenic Bacillus thuringiensis corn. Environmental Entomology, v.26, p.446-454, 1997.

RAPS, A.; KEHR, J.; GUGERLI, P.; MOAR, W.J.; BIGLER, F.; HILBECK, A. Immunological analysis of phloem sap of Bacillus thuringiensis corn and of nontarget herbivore Rhopalosiphum padi (Homoptera: Aphididae) for the presence of Cry1 Ab. Molecular Ecology, v.10, p.525-533, 2001.

REIS, L.L.; OLIVEIRA, L.J.; CRUZ, I. Biologia e potencial de Doru luteipes no controle de Spodoptera frugiperda. Pesquisa Agropecuária Brasileira, v.23, p.333-342, 1988.

ROMEIS, J.; DUTTON, A.; BIGLER, F. Bacillus thuringiensis toxin $(\mathrm{Cry} 1 \mathrm{Ab})$ has no direct effect on larvae of the green lacewing Chrysoperla carnea (Stephens) (Neuroptera: Chrysopidae). Journal of Insect Physiology, v.50, p.175-183, 2004.

SAS INSTITUTE. SAS onlinedoc: version 8. Cary, NC.: SAS Institute, 1999.

STEWART, S.D.; ADAMCZYK, J.R.; KNIGHTEN, K.S.; DAVIS, F.M. Impact of Bt cottons expressing one or two insecticidal proteins of Bacillus thuringiensis Berliner on growth and survival of Noctuid (Lepidoptera) larvae. Journal of Economic Entomology, v.94, p. $752-759,2001$.

WU, K.; GUO, Y.; LV, N.; GREENPLATE, J.T.; DEATON, R. Efficacy of transgenic cotton containing a crylAc gene from Bacillus thuringiensis against Helicoverpa armigera (Lepidoptera: Noctuidae) in Northern China. Journal of Economic Entomology, v.96, p.1322$1328,2003$.

ZWAHLEN, C.; NENTWIG, W.; BIGLER, F.; HILBECK, A. Tritrophic interactions of transgenic Bacillus thuringiensis corn, Anaphothrips obscurus (Thysanoptera: Thripidae), and the predator Orius majusculus (Heteroptera: Anthocoridae). Environmental Entomology, v.9, p.846-850, 2000.

Received May 18, 2006

Accepted March 23, 2007 